\title{
Histopathological and HPLC Analysis in the Hepatic Tissue of Pangasius sp. Exposed to Diclofenac
}

\author{
Vijaya Geetha, Roy Sujata, K. Subramaniyan Shreenidhi, \\ T.R. Sundararaman* \\ Department of Biotechnology, Rajalakshmi Engineering College, Thandalam, Chennai, India
}

Received: 8 March 2017

Accepted: 11 July 2017

\begin{abstract}
Pharmaceutics present in the environment are of growing concern for their potential consequences on human and ecosystem health. In long-term monitoring investigations of sewage and surface water samples, diclofenac was identified as one of the most important pharmaceutically active compounds. Pangasius sp. were exposed to determine the lethal concentration $\left(\mathrm{LC}_{50}\right)$ of diclofenac. The histopathological studies in a fish hepatopancreas sample showed significant changes like nucleation, differentiation, and hepatocytes. The large lesions and infiltration in hepatocytes were distinctly seen due to the toxic effect of diclofenac. In HPLC analysis, the control fish liver tissue showed no significant changes, whereas the diclofenac-exposed fish liver tissue showed a significant peak with a quicker run time. The studies confirmed that the diclofenac compound affects hepatocytes to a noteworthy extent. Therefore, this calls for reduction of diclofenac usage and also to have a checkpoint especially for diclofenac in the pharmaceutical effluent released into the water bodies.
\end{abstract}

Keywords: pharmaceutical industry, diclofenac, Pangasius sp.

\section{Introduction}

Galloping industrialization has led to great development, but also industrial pollution causing undesirable effects on natural resources. Industrial effluents are indiscriminately discharged into aquatic ecosystems without any pre-treatment, thereby creating serious problems to the non-target organisms. These non-target species are considered to be the most endangered by its action are probably aquatic organisms. The never-ceasing pollution results in large-

*e-mail: sundararaman.tr@rajalakshmi.edu.in scale disappearance of their flora and fauna and lowers social and economic value [1]. Many pharmaceutical effluents are not fully degraded in wastewater treatment plants and are continuously released in the aquatic environment, resulting in concentrations in the low $\mu \mathrm{g} / 1$ range in the receiving waters. Discharging of effluents into freshwater systems depletes the dissolved oxygen content, causing heavy mortality in fish by interfering with respiratory metabolism, liver damage, etc. [24]. Globally, in developing countries, 70 percent of industrial waste is dumped untreated into waters, where they pollute the usable water supply. The pharmaceutical industry along with various industries like chemical, fertilizer, etc., contributes to environmental pollution. 


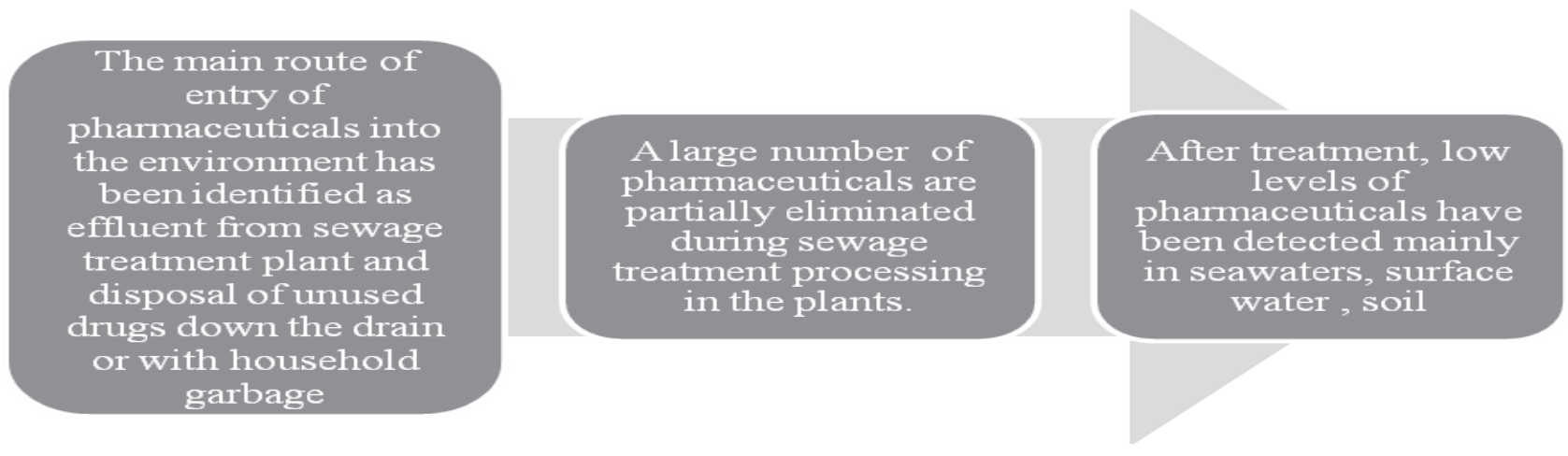

Fig. 1. Flow diagram for the entry of pharmaceuticals into the environment [8].

The pharmaceutical industry discovers, develops, produces, and markets drugs or pharmaceuticals for use as medication [5]. Urban wastewater seems to be the dominant emission pathway for pharmaceuticals globally, although emissions from industrial production, hospitals, agriculture, and aquaculture are important locally. India is the largest provider of generic drugs globally, with Indian generics accounting for $20 \%$ of global exports in terms of volume. Pharmaceuticals in the environment are of growing concern for their potential consequences on human and ecosystem health. Therefore, pharmaceutical effects on aquatic organisms have been investigated in acute toxicity assays [6-7].

The major compounds released from pharmaceutical effluents are clarithromycin, diclofenac, erythromycin, ethinylestradiol, roxithromycin, sulfamethoxsiol, trimethoprim, clofibrate, and phenolic compounds.

In long-term monitoring investigations of sewage and surface water samples, diclofenac was identified as one of the most important pharmaceutically active compounds present in the water cycle [9].

Diclofenac (sodium 2-[2-(2,6-dichloroanilino) phenyl]acetate is a widely used non-steroidal antiinflammatory drug (NSAID) and is persistent in the aquatic environment. Diclofenac represents an important drug in ambulatory care and is used to reduce pain, inflammation, and stiffness caused by many conditions, such as osteoarthritis, rheumatoid arthritis, abdominal cramps associated with menstruation, and ankylosing spondylitis [10]. It is used in the form of tablets, capsules, suppositories, and intravenous solutions, and in ointments and gels for dermal application [11]. The risk may be higher for people who take NSAIDs for a long time, are older in age, have poor health, or drink large amounts of alcohol while taking diclofenac. Diclofenac may cause side effects like diarrhea, constipation, gas or bloating, headache, dizziness, ringing in the ears, etc. Diclofenac is the only drug associated with an increased risk of liver damage $(95 \%$ confidence interval). Diclofenac caused liver disease in $85 \%$ of the patients within the first 6 months after drug intake.

We used bioinformatics tools to find the top genes interacting with diclofenac and to analyse the sequence similarity between Pangasius sp. and humans.

\section{Materials and Methods}

\section{Comparative Toxicogenomics Database}

The comparative Toxicogenomics database provides manually curated information about chemical-gene/ protein interactions, chemical-disease, and gene-disease relationships. The top interacting genes were found using this tool.

\section{Sample Collection}

Scientific Classification [12]

\section{Kingdom: Animalia \\ Phylum: Chordata \\ Class: Actinopterygii \\ Order: Siluriformes \\ Family: Pangasiidae \\ Genus: Pangasius}

Common names: striped catfish, irridescent shark catfish, Siamese shark, sutchi catfish

Maximum size: $100 \mathrm{~kg}(220 \mathrm{lb})$

Diet: Omnivore

Habitat: Freshwater

Panagasius sp. is among the endangered species with its population decreasing drastically. Pangasius sp. were bred in the coastal regions of Andra Pradesh and procured from a local dealer. The sharks were fed at regular intervals $(2 \mathrm{~mm}$ pellets consisting of worms and fish meal mixture). Sharks (Pangasius) were exposed to various concentrations of diclofenac after acclimatizing to the surrounding environment. The powdered diclofenac compound (commercially available and obtained from Sigma Aldrich) was diluted with HPLC-grade water, sonicated for 3 minutes, filtered, and added on to a tank containing a school of 6 fish. The lethal concentration 50 $\left(\mathrm{LC}_{50}\right)$ was determined after a series of trial exposures. The trial exposures were in the range $132 \mathrm{mg}, 264 \mathrm{mg}$, $396 \mathrm{mg}, 528 \mathrm{mg}, 660 \mathrm{mg}$, and $792 \mathrm{mg}$ for 11 litres of tank water. The $\mathrm{LC}_{50}$ was found as $264 \mathrm{mg}$ for $\sim 11$ litres of diclofenac-exposed fish. The liver tissue samples were collected for histopathological studies from the control group fish and the dead fish after exposure to diclofenac. 

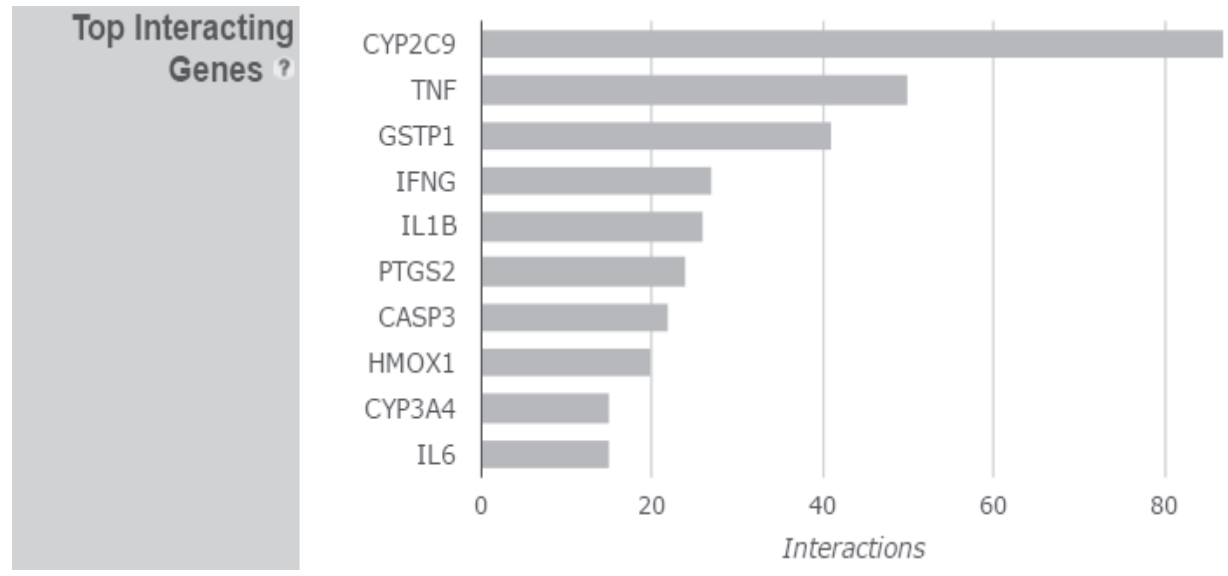

Fig. 2. Top interacting genes with the diclofenac compound.

The lifetime period was found to be $4 \frac{1}{4}$ days.

\begin{tabular}{|c|c|}
\hline Group 1 & Normal healthy fish $\mathrm{n}=6$ \\
\hline Group 2 & $\begin{array}{c}\text { Fish group exposed to diclofenac concentra- } \\
\text { tion of } 264 \mathrm{mg} \text { in } 11 \text { litres of water in fish tank } \\
\text { dimensions }(12 \times 6 \times 8) \text { inches }\end{array}$ \\
\hline
\end{tabular}

\section{Histopathological Examination}

The liver samples were fixed at $10 \%$ formalin solution in $10 \mathrm{ml}$ tubes. Fish-liver were sliced using microtome $(5 \mu \mathrm{m})$, embedded in paraffin, and stained with haematoxylin and eosin [13]. Histological changes in liver samples were examined using an Olympus multihead microscope (200x).

\section{High-Performance Liquid Chromatography}

HPLC was performed according to the modified protocol of Dubois [14]. The liver tissue of the shark fish were crushed and ground using $1.5 \mathrm{ml}$ tris buffer ( $\mathrm{pH} 10.3$ to $10.7 ; 0.1 \mathrm{M}$ ). For protein precipitation, $1 \mathrm{ml}$ sodium tungstate dehydrate $(0.15 \mathrm{M})$ and $100 \mu$ lacetic acid were added. The supernatant was conditioned with a $2 \mathrm{ml}$ mixture of methanol, water, and hexane (ratio
0.2:4.8:1.3). $10 \mu \mathrm{l}$ of this mixture was injected into the HPLC column (C18, waters system) with solvent system as methanol and water. Diclofenac commercially obtained from Sigma Aldrich was taken as control. The flowrate was maintained at $1 \mathrm{ml} / \mathrm{min}$.

\section{Results and Discussion}

\section{Comparative Toxicogenomics Database of Diclofenac}

On running the search for top interacting genes (Fig. 2), the CYP2C9 (cytochrome) gene was found to be the highest interacting gene with diclofenac followed by TNF (tumor necrosis factor) and GSTP1 (glutathione $\mathrm{S}$-transferase $\mathrm{P}$ 1). The gene regulation in zebrafish (Danio rerio) when exposed to diclofenac was elucidated and the genes WNT3A and WNT8A (wnt signaling pathway genes) were found [15]. In zebrafish, organic anion transporting polypeptide (OATP/Oatp) superfamily, Oatpld1 mediated the transport of diclofenac with very high affinity [16]. UGT1A1, UGT1A7, and UGT1B1 displayed good glucuronidation activities toward most phenolic aglycones and the 2 carboxylic acids (bilirubin and diclofenac) in zebrafish [17].

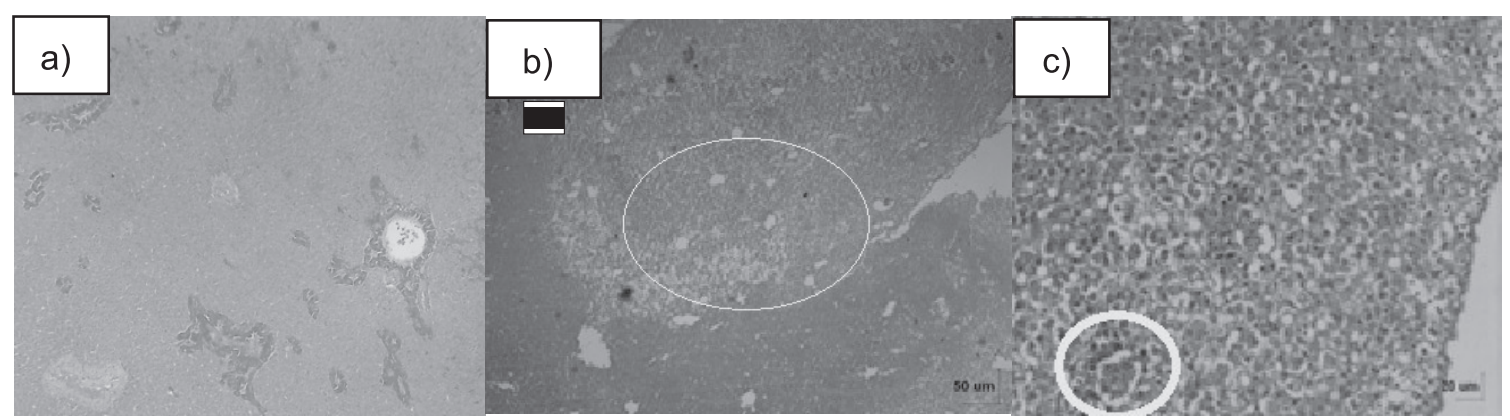

Fig. 3. Histological pictures of the liver of Pangasius, normal healthy fish and fish exposed to diclofenac: a) control (scale bar $=50 \mu \mathrm{m})$, b) diclofenac-exposed fish (conc: $12 \mathrm{mg} / 500 \mathrm{ml}$ ) showed large lesions along with infiltration in liver fats (scale bar $=50 \mu \mathrm{m}$ ), and c) difference in nucleation long with vacuolar degenerative changes in hepatocytes and hepatopancreas (scale bar $=20 \mu \mathrm{m}$ ). 

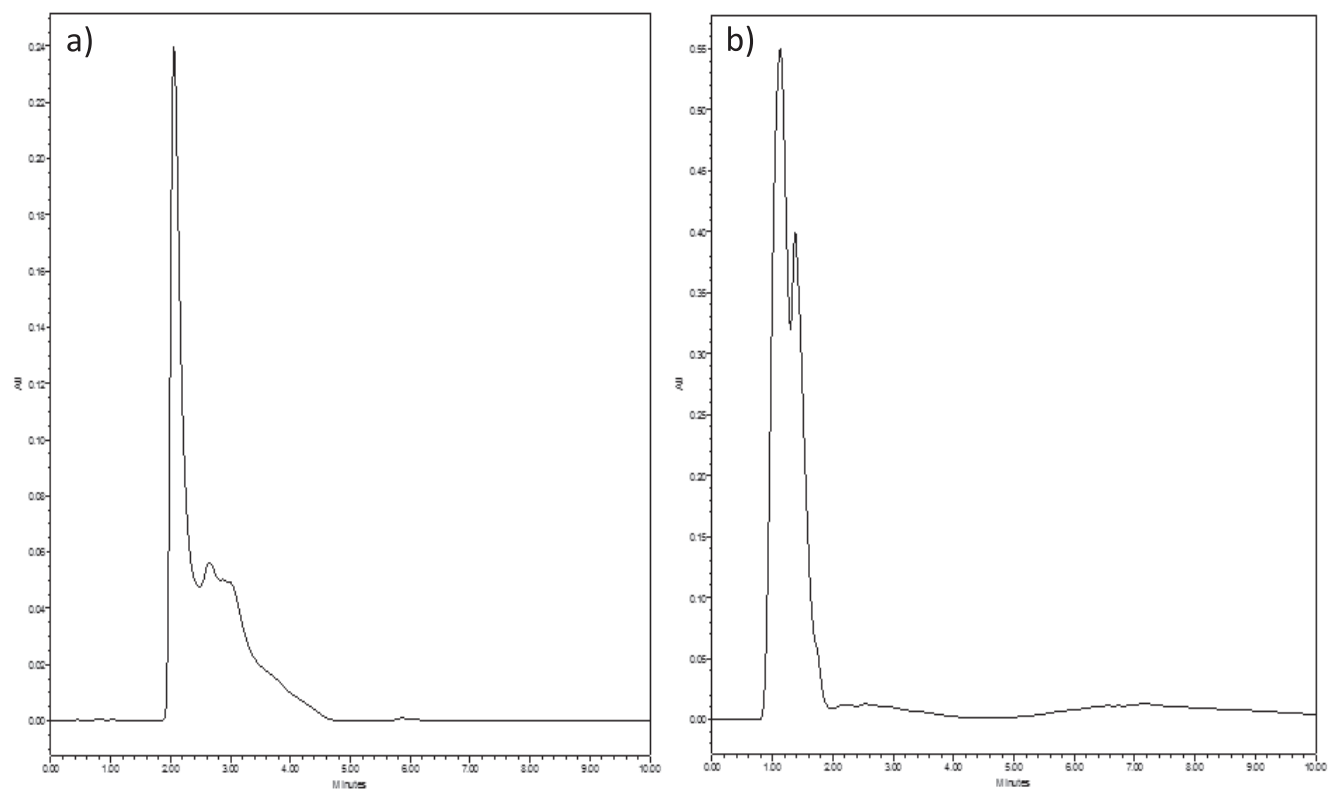

Fig. 4. High-performance liquid chromatography analysis of diclofenac: a) commercially available diclofenac (control) and b) liver tissue of fish exposed to diclofenac (sample).

\section{Results of Histopathological Studies}

Liver tissue of fish not exposed to diclofenac (control: normal healthy fish) appeared normal and the liver tissue architecture was found to be intact. Hepatocytes were arranged in cords between which were the liver sinusoids, but the hepatocytes of diclofenac-exposed fish samples showed significant changes.

Hepatocytes of the diclofenac-exposed fish appeared slightly swollen with large lesions (Fig. 3). Fat infiltration in liver tissue was observed. Changes in blood pressure (one of the side-effects of diclofenac) led to changes in the red blood cells of the liver. Vacuolation was distinctly seen in the parenchyma. Similar changes were seen when their diet was altered among rice, corn, and tapioca. Hepatocytes and hepatopancreas of Pangasius sp. showed degenerative changes, and the hepatocyte nuclei were condensed and darkly stained [13, 18]. Hepatocyte necrosis were observed in liver and muscle tissues of Tilapia guinensis, exposed to heavy metals [19]. These hepatocyte changes were also observed in Pangasius exposed to diclofenac. Pesticide rogorintreated fish kidney tissues exhibited tubular epithelial cell degeneration, and rogorin-treated liver tissues showed signs of cell wall rupture, cytoplasm became granulated and vacuolated, and damaged vacuolar degeneration of hepatocytes were observed in Clarius batrachus [20].

\section{HPLC Analysis of Diclofenac}

The control fish liver tissue and the liver tissue of the fish exposed to diclofenac were processed for HPLC analysis. We found that the control fish liver tissue chromatogram showed no significant changes. The diclofenac (standard) showed a peak value $0.85 \mathrm{AU}$ and the diclofenac-exposed tissue sample showed a peak of $0.24 \mathrm{AU}$. The diclofenac-exposed liver tissue sample showed a little quick run time compared to the chromatogram of the standard diclofenac sodium compound (shown in Fig. 4).

In the research article by Islas Flores [21], he evaluated potential diclofenac-induced oxidative stress in brain, liver, gill, and blood of $C$. carpio. The pharmaceutical agent diclofenac is concluded to induce oxidative stress on the common carp C. carpio, with the highest incidence of oxidative damage occurring in liver and gill. Acute exposure to diclofenac, even at low concentrations, caused hematologic and renal enzymatic alterations in $R$. quelen [22]. When Cyprinus carpio was exposed to diclofenac and clofibric acid, it was found that there were significant changes [23].

These findings were found to be in accordance with our work on the toxic effect of diclofenac studied in Pangasius sp. Also, the top interacting gene with this compound was found as $\mathrm{CYP} 2 \mathrm{C}$. CYP2C9 is the most

Level of diclofenac in liver tissue of Pangsius sp. exposed to experimental conditions

\begin{tabular}{|c|c|}
\hline Normal Healthy fish $(\mathrm{N}=6)$ & Fish exposed to Diclofenac $\mathrm{N}=6$ (Concentration in $\mu \mathrm{g} / \mathrm{mg}$ of liver $)$ \\
\hline- & $0.0054 \pm 0.0019^{*}$ \\
\hline
\end{tabular}

Results are represented as mean \pm standard deviation, significance at ${ }^{*} \mathrm{p}<0.05$ 
important drug-metabolizing enzyme in eukaryotes [24]. It plays major role in the oxidation of both xenobiotic and endogenous compounds and is involved in many clinically important drug interactions.

\section{Conclusions}

From the present research work we concluded that the top interacting gene with diclofenac compound was CYP2C9. This gene was responsible for the process, absorption, distribution, metabolism, excretion, and toxicity (ADMET) of the pharmaceutical drug when consumed. A down regulation of this gene when an excessive amount of diclofenac gets accumulated may lead to the failure of liver function. This alteration in gene function has led to significant lesions in hepatic tissue found by histopathological studies, and diclofenac accumulation in liver tissue observed through the significant peak formation in HPLC analysis. Hence, there is a need to reduce the rate of consumption of painkillers like diclofenac in order to avoid the side effects in the longer run.

\section{Acknowledgements}

We extend our thanks to AICTE for providing financial support (No. 8-119/RFID/RPS/POLICY-3/2013-14).

\section{References}

1. PADMINI E., VIJAYAGEETHA B. Biodegradative Efficiency of Recombinant Escherichia Coli on Heavy Metal Contaminants and Organic Pollutants from Ennore Estuary. Asian Journal of Microbiology, Biotechnology \& Environmental Sciences Paper. 10 (1), 185, 2008.

2. CHANTI BABU PATNEEDI, DURGA PRASADU Impact of Pharmaceutical Wastes On Human Life And Environment, Rasayan J. Chem, 8 (1), 67, 2015.

3. KATHRYN E. ARNOLD A. ROSS BROWN GERALD, T. ANKLEY JOHN, SUMPTER P. Medicating the environment: assessing risks of pharmaceuticals to wildlife and ecosystems. Philosophical transactions of the Royal Society B, 369 (1656), 2014.

4. GAW S., THOMAS K.V., HUTCHINSON T.H. Sources, impacts and trends of pharmaceuticals in the marine and coastal environment, Philosophical transactions of the Royal Society B, 2014.

5. MCGUIRE JOHN L., HASSKARL HORST BODE, GERD KLINGMANN, INGRID ZAHN, MANUEL, Pharmaceuticals-General Survey. Ullmann's Encyclopedia of industrial chemistry, 2007.

6. HALLARE A.V., KOHLER H. R.,TRIEBSKORN R, Developmental toxicity and stress protein responses in zebrafish embryos after exposure to diclofenac and its solvent, DMSO. Chemosphere. 56 (7), 545, 2004.

7. VAN DEN BRANDHOF AND MONTFORTS M., Fish embryo toxicity of carbamazepine, diclofenac and metoprolol. Ecotoxicology and environmental safety. $\mathbf{7 3}$ (8), 1862, 2010.
8. PRASKOVA E., VOSLAROVA E., SIROKA Assessment of diclofenac $\mathrm{LC}_{50}$ reference values in juvenile and embryonic stages of the zebrafish. Polish journal of veterinary sciences, 14 (4), 545, 2011.

9. HEBERER T., Occurrence, fate, and removal of pharmaceutical residues in the aquatic environment: a review of recent research data. Toxicology Letters. 131 (1-2), 5, 2002.

10. EVA PRASKOVA, LUCIE PLHALOVA, LUCIE CHROMCOVA, STANISLAVA STEPANOVA, IVETA BEDANOVA, JANA BLAHOVA, MARTIN HOSTOVSKY,MISASKORIC, PETR MARŠÁLEK, EVA VOSLAROVA, AND ZDENKA SVOBODOVA., Effects of Subchronic Exposure of Diclofenac on Growth, Histopathological Changes, and Oxidative Stress in Zebrafish (Danio rerio). The Scientific World Journal. 2014, 2014.

11. BUSER H.R., POIGER T., MULLER M.D., Occurrence and fate of the pharmaceutical drug diclofenac in surface waters: rapid photodegradation in a lake, Environmental Science and Technology, 32 (22), 3449, 1998.

12. SAUVAGE, Pangasius hypophthalmusas seen by World Register of Marine Species, 1878.

13. YENGKOKPAM S., SAHU N.P., PAL A.K., MUKHERJEE S.C., DEBNATH D., Haematological and hepatic changes in Catla catla fingerlings in relation to dietary sources and levels of gelatinized carbohydrate.Acta Ichthyol. Piscat. 35 (2), 87, 2005.

14. DUBOIS, FLUCHARD, SIOR, DELAHAUT, Identification and quantification of five macrolide antibiotics in several tissues, eggs and milk by liquid chromatographyelectrospray tandem mass spectrometry, J Chromatogr B Biomed Sci Appl., 5, 189, 2001.

15. CHEN J.B., GAO H.W., ZHANG Y.L., ZHANG Y., ZHOU X.F., LI C.Q., GAO H.P. Developmental toxicity of diclofenac and elucidation of gene regulation in zebrafish (Daniorerio). Sci. Rep., 4 (4841), 1, 2014.

16. POPOVIC M., ZAJA R., FENT K., SMITAL T., Interaction of environmental contaminants with zebrafish organic anion transporting polypeptide, Oatpld1 (Slcold1). Toxicol Appl Pharmacol., 1; 280 (1), 149, 2014.

17. WANG Y., HUANG H., WU Q. Characterization of the zebrafish Ugt repertoire reveals a new class of drug-metabolizing UDP glucuronosyltransferases. Mol Pharmacol. 86 (1), 62, 2014.

18. REZA SEYRAFI, GHOLAMREZA NAJAFI, HOOMAN RAHMATI-HOLASCO, Histological study of Hepatopancreas in Iridescent Shark Catfish (Pangasius hypopthalmus). Journal of Animal and Veterinary Advances. 8 (7), 1305, 2009.

19. JUSTINA I.R., Histopathological changes in liver and muscle of Tilapia fish from QIRE exposed to concentrations of heavy metals., International journal of biological, biomolecular, agricultural, food and biotechnological engineering, 9 (6), 637, 2015.

20. HELAN CHANDRA, SAJDA S. SRIDHAR Acute toxicity studies on the fresh water fish Clarias batrachus exposed to pesticide rogorin., Journal of chemical and pharmaceutical sciences. 8 (1), 34, 2015.

21. ISLAS FLORES, LEOBARDO MANUEL GÓMEZOLIVÁN, MARCELA GALAR-MARTÍNEZ, ARTURO COLÍN-CRUZ, NADIA NERI-CRUZ, SANDRA GARCÍA-MEDINA Diclofenac-Induced Oxidative Stress in Brain, Liver, Gill and Blood of Common Carp (Cyprinus carpio). Ecotoxicology and Environmental Safety. 92, 32, 2013. 
22. GHELFI A., RIBAS J.L.C., GUILOSKI I.C., BETTIM F.L., PIANCINI L.D.S., CESTARI M.M., PEREIRA A.J., SASSAKI G.L., SILVA DE ASSIS H.C. Evaluation of Biochemical, Genetic and Hematological Biomarkers in a Commercial Catfish Rhamdia quelen Exposed to Diclofenac, Bulletin of Environmental Contamination and Toxicology, 96 (1), 49, 2016.

23. SARAVANAN M., KARTHIKA S., MALARVIZHI A., RAMESH M. Ecotoxicological Impacts of Clofibric
Acid and Diclofenac in Common Carp (Cyprinus Carpio) Fingerlings: Hematological, biochemical, Ionoregulatory and Enzymological Responses. Journal of Hazardous Materials. 195, 188, 2011.

24. ZI J., LIU D., MA P., HUANG H., ZHU J., WEI D., YANG J., CHEN C., Effects of CYP2C9*3 and CYP2C9*13 on diclofenac metabolism and inhibition-based drug-drug interactions. Drug Metab Pharmacokinet. 25, 343, 2010. 